\title{
Characterization of noise emitted by a power tiller through geostatistics
}

\author{
Luana M. Gonçalves ${ }^{1}$, Gabriel A. e S. Ferraz ${ }^{1}$, Marcelo S. de Oliveira ${ }^{2}$, \\ Brenon D. S. Barbosa ${ }^{1}$, Carlos J. da Silva ${ }^{3}$ \& Patrícia F. P. Ferraz ${ }^{1}$ \\ ${ }^{1}$ Universidade Federal de Lavras/Departamento de Engenharia. Lavras, MG, Brasil. E-mail: luanna_mendess@yahoo.com.br (Corresponding author) - \\ ORCID: 0000-0001-8406-2820; gabriel.ferraz@deg.ufla.br - ORCID: 0000-0001-6403-2210; b.diennevan@outlook.com - ORCID: 0000-0001-6791-2504; \\ patricia.ponciano@deg.ufla.br - ORCID: 0000-0002-9708-0259 \\ ${ }^{2}$ Universidade Federal de Lavras/Departamento de Estatística. Lavras, MG, Brasil. E-mail: marcelo.oliveira@des.ufla.br - ORCID: 0000-0003-3127-7195 \\ ${ }^{3}$ Universidade Federal Rural do Rio de Janeiro/Colégio Técnico da UFRRJ. Seropédica, RJ, Brasil. E-mail: carlosjose19621@gmail.com - ORCID: 0000- \\ 0001-8405-0221
}

\begin{abstract}
Noise is one of the harmful and stressful physical agents present in the workplace. Research performed with geostatistics to adjust the semivariogram of tractor noise were performed using the Gaussian and spherical model. In this way, the aim was to map the spatial variability of the noise emitted by a power tiller through the sine wave model, besides testing other fitting methods, in order to identify health zones for the workers. The experiment was performed with an agricultural power tiller $(10.3 \mathrm{~kW})$ placed in a working regime $(1500 \mathrm{rpm})$, coupled to a brushcutter, and a digital sound level meter to collect noises in points distributed along a regular grid sampling of $2.0 \times 2.0 \mathrm{~m}$ around the tractor. The spatial dependence of noise was analyzed through semivariogram fitting by different methods and by the wave model to obtain the spatial distribution map interpolated by kriging. It was possible to characterize the structure and the magnitude of the spatial dependence of the noise levels emitted by the tractor, as well as to map the spatial distribution. A maximum noise level of $96.5 \mathrm{~dB}$ was observed close to the tractor engine, a value above the limit of $85.0 \mathrm{~dB}$ for $8 \mathrm{~h}$ of daily exposure (NR-15). Thus, the use of ear protectors is recommended for both the tractor driver and the professionals who support agricultural operation within a radius of $6 \mathrm{~m}$ from the emitting source under the conditions studied.
\end{abstract}

Key words: acoustic comfort, agricultural mechanization, spatial variability, ergonomics, sine wave model

\section{Caracterização do ruído emitido por um trator de rabiça por meio da geoestatística}

RESUMO: O ruído é um dos agentes físicos nocivos e estressantes presente no ambiente de trabalho. Pesquisas realizadas com a geoestatistica para ajuste de semivariograma de ruído de tratores foram feitos por meio do modelo gaussiano e esférico. Dessa forma, objetivou-se mapear a variabilidade espacial do ruído emitido por um trator de rabiça, por meio do modelo de onda senoidal e testando outros métodos de ajuste, visando identificar zonas de salubridade para os trabalhadores. $\mathrm{O}$ experimento foi desenvolvido com um trator de rabiça agrícola $(10.3 \mathrm{~kW})$ colocado em regime de trabalho $(1500 \mathrm{rpm})$, acoplado a uma roçadora, e um decibelímetro digital para a coleta dos ruídos em pontos distribuídos numa malha amostral regular de $2.0 \times 2.0 \mathrm{~m}$ ao redor do trator. A dependência espacial do ruído foi analisada por meio de ajuste de semivariograma por diferentes métodos e pelo modelo wave para obtenção do mapa de distribuição espacial interpolados por krigagem. Foi possível caracterizar a estrutura e a magnitude da dependência espacial dos níveis de ruído emitidos pelo trator, bem como realizar o mapeamento da distribuição espacial. Observou-se valor máximo de nível de ruído de $96.5 \mathrm{~dB}$ próximo ao trator, valor acima do limite permitido de $85.0 \mathrm{~dB}$ para $8 \mathrm{~h}$ de exposição diária (NR-15). Assim, o uso de protetores auriculares é recomendado tanto para o tratorista quanto para os profissionais que dão suporte à operação agrícola em um raio de $6 \mathrm{~m}$ da fonte emissora, nas condições estudadas.

Palavras-chave: conforto acústico, mecanização agrícola, variabilidade espacial, ergonomia, modelo de onda senoidal 


\section{INTRODUCTION}

The use of power tiller as an energy source is often used in family farming and can be a tool to optimize work. Due to the small size and low power of the power tiller, between 7.35 and $14.71 \mathrm{~kW}$, these are widely used in small properties and in rugged relief regions (Veiga et al., 2015). However, machines and equipment can provide unhealthy conditions in their operations.

Agricultural work when aided by agricultural machinery exposes the worker to agents harmful to their health and physical integrity, such as: noise from the engines and implements, vibration, gases and dust particles, among other agents (Poje et al., 2016). This exposure to high noise levels emitted by machines can lead to hearing loss and can cause stress, affecting worker performance and workplace efficiency (Alves et al., 2011).

Regarding agricultural machinery, the Regulatory Standard (NR-15) (MTE, 2017) foresees additional of insalubrity to workers who are exposed to continuous or intermittent noise, heat, vibrations, chemical agents and dust. For continuous or intermittent noise, the NR-15 states that exposure to noise levels above $115.0 \mathrm{~dB}$ is not permitted for individuals not adequately protected. Furthermore, this standard establishes the time in which a person may be exposed to each level of noise.

When using geostatistics for semivariographic analysis of noise, a data oscillation is observed due to the physical characteristic of the noise, because it is a sound wave. There are periodic models for this type of behavior that best fit these types of phenomena (Webster \& Oliver, 2007).

It should be emphasized that most of the studies that evaluated the noise produced by agricultural machines using geostatistics conformed to the Gaussian model (Pimenta Junior et al., 2012; Yanagi Junior et al., 2012; Missio et al., 2015; Spadim et al., 2015). Ferraz et al. (2013) analyzed the noise of portable coffee harvesters and assembled the spherical model. The probable causes of non-detection of a periodic structure for the semivariogram of these authors are sample grid, environmental effects and experimental design.

Based on the above, the objective of present study was to evaluate the spatial variability of the noise emitted by a power tiller through the sine wave model and to test other methods of assembly through geostatistics for the observation and definition of health zones for the operators and workers involved in operations.

\section{Material And Methods}

The experiment was conducted at the Technical College of the Federal Rural University of Rio de Janeiro (CTUR),

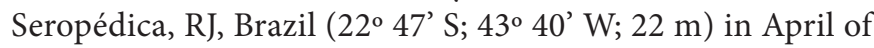
2013. A power tiller coupled to a brushcutter with a nominal power of $10.3 \mathrm{~kW}$ and a rotation of $1500 \mathrm{rpm}$ was used to drive the rotary brushcutter.

Noise levels were determined using sound level meters in the slow response circuit and "A" equalization, expressed in $\mathrm{dB}$, being that the wind shield of this meter was used for all measurements. The noise level evaluations were performed according to the methodology described in NBR 9999 (ABNT, 1987), in which the ambient temperature was between -5 and $30^{\circ} \mathrm{C}$ and the air velocity was less than $5.0 \mathrm{~m} \mathrm{~s}^{-1}$. On the day of the experiment, the wind speed and temperature were $2.6 \mathrm{~m} \mathrm{~s}^{-1}$ and $26^{\circ} \mathrm{C}$, respectively, meeting the standard requirements.

The readings were performed at the average height of the operator's ear, at points distributed in a regular grid sampling of $2.0 \times 2.0 \mathrm{~m}$, totaling 121 sampling points, around the operating agricultural machine. A spatial coordinate was measured in meters where the center point $(0,0)$ corresponded to the place where the agricultural machine remained in operation during the entire collection. The center point $(0,0)$ corresponds to the operator seat.

The spatial dependence of the noise produced by the operating power tiller was analyzed through a classic and robust semivariogram fitting. The classic semivariogram was estimated by the Eq. 1:

$$
\hat{\gamma}(h)=\frac{1}{2 N(h)} \sum_{\substack{\forall\left(x_{i}, x_{j}\right) \\\left|x_{i}-x_{j}\right|-h}}\left[Z\left(x_{i}\right)-Z\left(x_{j}\right)\right]^{2}
$$

where:

$\mathrm{N}(\mathrm{h})$ - number of experimental pairs of observations separated by the distance $\mathrm{h}$; and,

$\mathrm{Z}\left(\mathrm{x}_{\mathrm{i}}\right)$ and $\mathrm{Z}\left(\mathrm{x}_{\mathrm{j}}\right)$ - random variables at the locations $\mathrm{x}_{\mathrm{i}}$ and $\mathrm{x}_{\mathrm{j}}$.

The semivariogram is represented by the graph $\gamma(\mathrm{h})$ versus $\mathrm{h}$. With the adjustment of a mathematical model to the calculated values of $\gamma(\mathrm{h})$, the coefficients of the theoretical model were estimated for the semivariogram. They are: nugget effect $\left(\mathrm{C}_{0}\right)$; sill $\left(\mathrm{C}_{0}+\mathrm{C}_{1}\right)$ and range, as described by Yanagi Junior et al. (2012).

According to Cressie \& Hawkins (1980), the robust estimator of semivariogram values is less susceptible to the influence of mass data values than the classic estimator. Thus, the robust estimator is described by Eq. 2:

$$
\hat{\gamma}(\mathrm{h})=\frac{1}{2} \frac{\left[\mathrm{N}(\mathrm{h})^{-1} \sum_{\mathrm{N}(\mathrm{h})} \sqrt{|(\mathrm{Z}(\mathrm{x}+\mathrm{h})-\mathrm{Z}(\mathrm{x}))|}\right]^{4}}{0.457+\frac{0.494}{\mathrm{~N}(\mathrm{~h})}}
$$

where:

$\mathrm{N}(\mathrm{h})$ - number of experimental pairs of observations; and, $\mathrm{Z}(\mathrm{x}), \mathrm{Z}(\mathrm{x}+\mathrm{h})$ - separated by a distance $\mathrm{h}$.

This estimator assumes that the differences $\mathrm{Z}(\mathrm{x}+\mathrm{h})-\mathrm{Z}(\mathrm{x})$ are distributed normally for all pairs $(\mathrm{x}+\mathrm{h}, \mathrm{x})$.

The fitting of semivariograms methods was chosen as a function of Ordinary Least Squares (OLS) and Weighted Least Squares (WLS), estimated by classic and robust mode. The wave model was tested for all methods (Webster \& Oliver, 2007) Eq. 3 , totaling four semivariograms for the variable under study.

$$
\hat{\gamma}(\mathrm{h})=\mathrm{C}_{\mathrm{o}}^{2}+\frac{\mathrm{a}}{\mathrm{h}} \operatorname{sen}\left(\frac{\mathrm{h}}{\mathrm{a}}\right)^{4}
$$

where:

$\mathrm{C}_{0}$ - nugget effect; 
a - range; and,

h - distance between samples.

A third degree polynomial was used to remove the trend that might interfere with the spatial dependence of data, and thus fitted the semivariograms to the residuals and later added the residuals with the tendency to obtain the final map.

For the choice of semivariogram fitting methods, the cross-validation of data was considered according to the methodology used by Ferraz et al. (2012).

According to Isaaks \& Srivastava (1989) and Mueller et al. (2004), cross-validation is the error estimation technique that allows comparing predicted values with the sampled ones. The sample value, at a certain location $\mathrm{Z}\left(\mathrm{s}_{\mathrm{i}}\right)$, is temporarily discarded from the data set, and then a kriging prediction is performed on the location $\mathrm{Z}\left(\mathrm{s}_{(\mathrm{i})}\right)$, using the remaining samples. Thereby, it is possible to extract some values very useful for choosing the method, such as the mean error (ME), the standard deviation of mean errors $\left(\mathrm{SD}_{\mathrm{ME}}\right)$, the reduced mean error $(\mathrm{RE})$, and the standard deviation of reduced mean errors $\left(\mathrm{SD}_{\mathrm{RE}}\right)$.

The selection criteria based on cross-validation should find the value of $\mathrm{ME}$ and $\mathrm{RE}$ closest to zero, the value of $\mathrm{SD}_{\mathrm{ME}}$ should be the lowest, and the value of $\mathrm{SD}_{\mathrm{RE}}$ should be closest to one.

After the semivariogram fitting, the data were interpolated by universal kriging in order to allow visualizing spatial distribution patterns of the noise emitted by this agricultural machine.

The geostatistical analysis was performed using the $\mathrm{R}$ Development Core Team computer system (R Development Core Team, 2017), through the geoR package (Ribeiro Junior \& Diggle, 2001). For the evaluation of health levels, the values recommended by NR 15 (MTE, 2017) were used. The layout of maps were generated by the free and open-source software QGIS version 2.14.15 (Quantum GIS Development Team, 2017).

\section{Results AND Discussion}

By analysing the minimum and maximum limits, the coefficient of variation and the average noise emitted by the power tiller (Table 1), a data variation is observed.

However, this analysis solely not allow stating where there is the highest or the lowest values of noise emitted by the tractor, thus requiring geostatistical studies.

Table 1. Descriptive statistics of noise emitted $(\mathrm{dB})$ by a power tiller

\begin{tabular}{lll|lllll} 
Min & Max & $\mathbf{x}$ & Md & SD & Var & CV & K
\end{tabular}

$\begin{array}{llllllll}73.5 & 96.5 & 80.10 & 79.30 & 4.47 & 19.95 & 5.6 & 1.27\end{array}$

Min - Minimum value of the variable; Max - Maximum value of the variable; $x$ - Average; Md - Median; SD - Standard deviation; Var - Variance; CV - Coefficient of variation (\%); $\mathrm{K}$ - Coefficient of kurtosis
The semivariogram and its parameters (nugget effect, $\mathrm{C}_{0}$; contribution, $\mathrm{C}_{1}$; sill, $\mathrm{C}_{0}+\mathrm{C}_{1}$; range, a; and practical range, a') were obtained by fitting different wave model methods (Table 2).

According to Pyrcz \& Deutsch (2003), the wave model is often used to indicate cycles or periodicity. Since the noise is a sound wave, such a model was very well adapted to the data, having a faithful fit to the cyclic behavior of the sound Figure 1.

In order to perform kriging, some semivariogram parameters must be estimated accurately. Otherwise, it will result in an ordinary kriging with estimation errors and erroneous information about the phenomenon (Ferreira et al., 2013). In this way, the wave model is the most suitable model for noise adjustment than other models, such as Gaussian and spherical, which may incur in estimation errors.

The best adjusted method was the weighted least square (WLS), in which the values of ME and RE were the closest to zero and the value of $\mathrm{SD}_{\mathrm{RE}}$ was the closest to one (Table 2), according to the methodology proposed by Ferraz et al. (2012).

According to NR 15 (MTE, 2017), considering $8 \mathrm{~h}$ a day, a worker can be exposed only to $85.0 \mathrm{~dB}$. When analysing Figure 2 , it can be noted that the noise values emitted by the tractor around the operating agricultural machine were higher than those recommended by the standard, up to $7 \mathrm{~m}$ in the front, 5 $\mathrm{m}$ in the left side, $3 \mathrm{~m}$ in the rear and $7 \mathrm{~m}$ in the right side of the engine, where is located the engine exhaust.

It is also observed that in the center map, where is the operator, the noise level measured was $91 \mathrm{~dB}$ (Figure 2), with the red coloration. According to the values recommended by

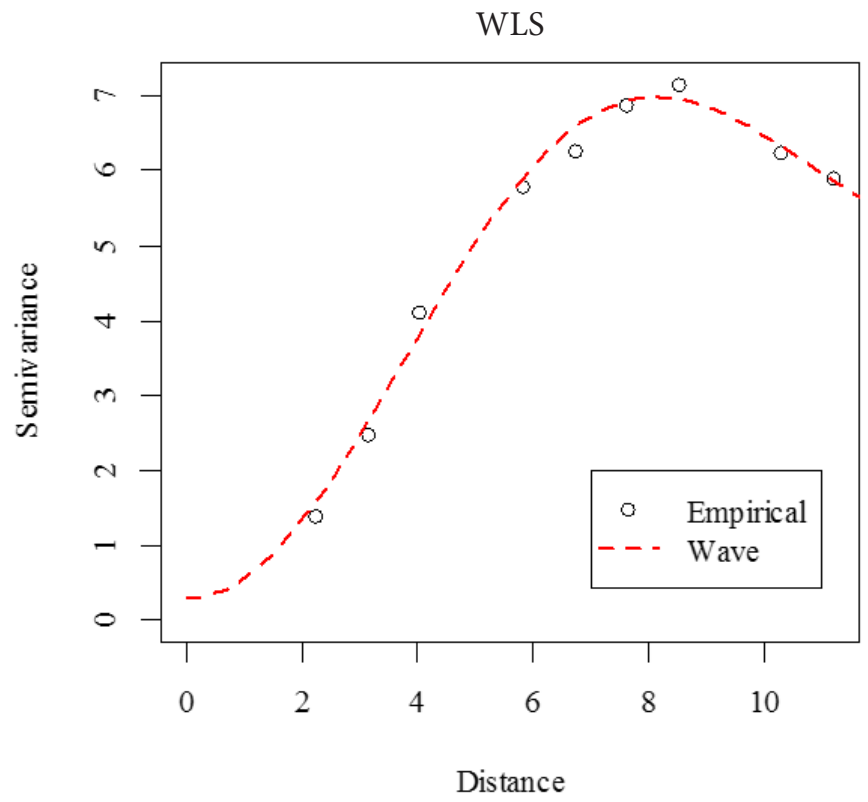

Figure 1. Semivariogram of the noise emitted by the power tiller fitted by the sine wave model

Table 2. Estimated methods, models and parameters of the experimental semivariograms for the noise variables emitted by the power tiller

\begin{tabular}{llllllllll}
\multicolumn{1}{c}{ Method } & Model & $\mathbf{C}_{\mathbf{0}}$ & $\mathbf{C}_{1}$ & $\mathbf{a}$ & $\mathbf{a}^{\mathbf{3}}$ & $\mathbf{M E}$ & $\mathbf{S D}_{\mathrm{ME}}$ & $\mathbf{R E}$ & $\mathbf{S D}_{\mathrm{hE}}$ \\
\hline OLS & Sine wave & 0.21 & 5.53 & 1.83 & 5.46 & 0.01 & 0.86 & 0.01 & 1.64 \\
WLS & Sine wave & 0.30 & 5.48 & 1.81 & 5.43 & 0.01 & 0.86 & 0.01 & 1.38 \\
Robust OLS & Sine wave & 0.13 & 3.81 & 1.85 & 5.54 & 0.01 & 0.86 & 0.01 & 2.09 \\
Robust WLS & Sine wave & 0.16 & 3.82 & 1.84 & 5.52 & 0.01 & 0.86 & 0.01 & 1.90 \\
\hline
\end{tabular}

$\mathrm{C}_{0}$ - Nugget effect; $\mathrm{C}_{1}$ - Contribution; $\mathrm{C}_{0}+\mathrm{C}_{1}$ - Sill; a - Range; a' - Practical range; ME - Mean error; $\mathrm{SD}_{\mathrm{ME}}-\mathrm{Standard}$ deviation of mean error; RE - Reduced mean error; $\mathrm{SD} \mathrm{RE}_{\mathrm{BE}}-\mathrm{Standard}$ deviation of reduced mean errors; OLS - Ordinary least squares; WLS - Weighted least squares 


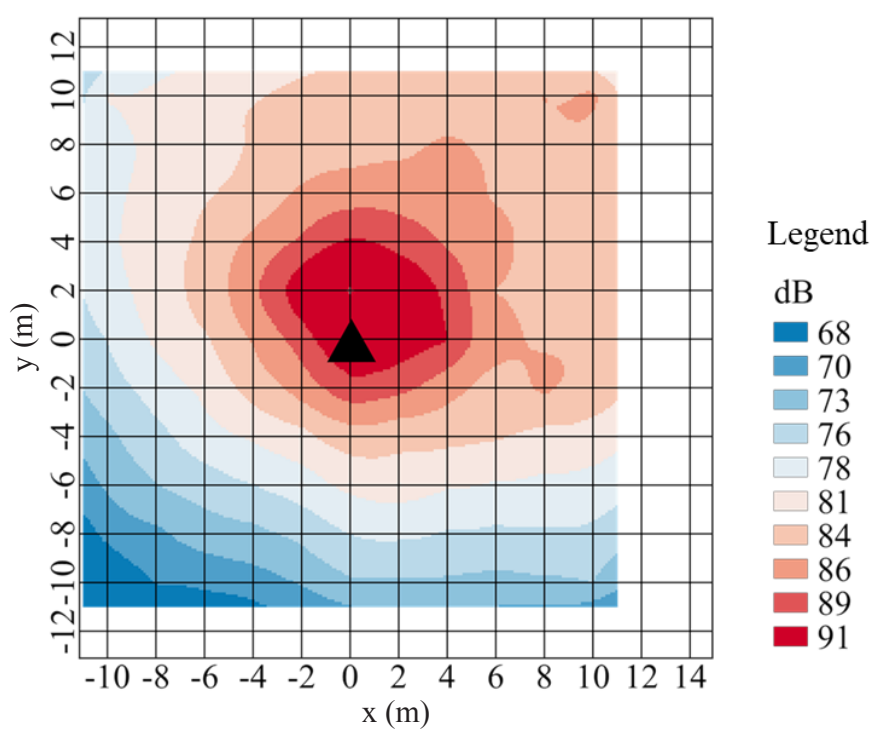

Figure 2. Spatial distribution map of the noise emitted by the power tiller

NR 15 (MTE, 2017), for this noise level, the allowable daily exposure limit is $3 \mathrm{~h}$ without the use of ear protection devices during its execution.

The maximum noise value, $96.5 \mathrm{~dB}$ (Table 1 ), was observed at point $(0,2)$, which was the measured near the tractor engine (source of noise), represented by the red color in the map. Under these conditions, according to the standard NR 15 (MTE, 2017), the worker only could be exposed to this noise up to $1 \mathrm{~h}$ and $45 \mathrm{~min}$ daily.

Studying some models of tractors, Gonçalves et al. (2013) found that for an $8 \mathrm{~h}$ working day the noise levels of the tractors were above the level allowed by NR 15. Baesso et al. (2015) evaluated 12 tractors of different models and concluded that tractors without a closed cabin had noise levels close to the operator's ear above the levels allowed by NR 15, being necessary the use of ear protectors. Studies performed by Rinaldi et al. (2008), Alves et al. (2011) and Nascimento et al. (2013) also concluded that farm machinery noise levels were above tolerance limits, being needed to take measures to reduce or eliminate the risk which the workers were exposed in the agricultural operations.

It was observed, still in Figure 2, that the more distant the tractor, the more bluish the spots, signaling the noise level decrease, thus becoming more appropriate to the workers and not requiring the compulsory use of Personal Protective Equipment (PPE). However, the use of PPE is still recommended for all workers involved in this machine operation. The minimum noise value produced by this tractor was around $73.5 \mathrm{~dB}$ (Table 1) observed in point $(4,-10)$, i.e., the farthest from the source, corroborating with results found by Magalhães et al. (2012); Pimenta Junior et al. (2012); Nascimento et al. (2013) and Missio et al. (2015).

It is also observed that the noise levels spread in the northeastern direction of the map, and although the measurements were according to the standard, this result may have been influenced by the wind, since the wind is a propagation way of the noise, thus being recommended research regarding the wind influence on noise levels.
High noise levels may compromise the health of the worker. According to Brisolin et al. (2012), these loud noise levels can cause physiological changes in heart rate and blood pressure, sleep disturbances, digestive, vestibular, neurological and behavioral disorders, such as irritation, fatigue, decreased productivity, noise intolerance, anxiety, depression and stress.

Fernandes \& Morata (2002) studied machine noise levels and observed an extreme discomfort for the machine operator, where workers exposed to this risk complain of hearing loss and tinnitus, besides several other symptoms as headache, nervousness, and stomach problems.

According to Guida et al. (2014), noise is the main physical causative agent of Noise-Induced Hearing Loss (NIHL). NIHL also causes stress and impair an effective communication at work, leading to work related accidents (Leão \& Dias, 2010).

The noise levels found in this study are above the legislation and exceed the standard limits, classified as unhealthy zones, in which up to $6 \mathrm{~m}$ in the front, $5 \mathrm{~m}$ in the right side, $4 \mathrm{~m}$ in the left side and $3 \mathrm{~m}$ in the rear of the power tiller, measures are recommended in order to reduce noise levels at source, or the operator and workers involved in the operations shall use the PPE in the whole $8 \mathrm{~h}$ working day, since this zone exceeded the tolerance limits, according to the standard (Figure 3).

It can be stated that apart a distancing radius of $6 \mathrm{~m}$ from the power tiller, the operators will be in the health zone for this machine and for these conditions.

In this way, the existence of an unhealthy situation is evident for the operator and the support worker to the agricultural operation, as presented in Figure 3, with red color. At some points, farther from the emitting source, values below $85.0 \mathrm{~dB}$ were identified, but already enough to generate stress situations.

To reduce such unhealthy effects, the ideal would be to reduce the noise source, according to Gonçalves et al. (2009). However, it is often tough to deploy a cabin, e.g., in power tiller due to their robustness, thus adopting prevention, comfort and safety measures, such as the use of PPE as well as awareness and training of operators and support workers on a continuous basis is mostly recommended. Two types of PPE recommended in this case: earmuffs and earplugs.

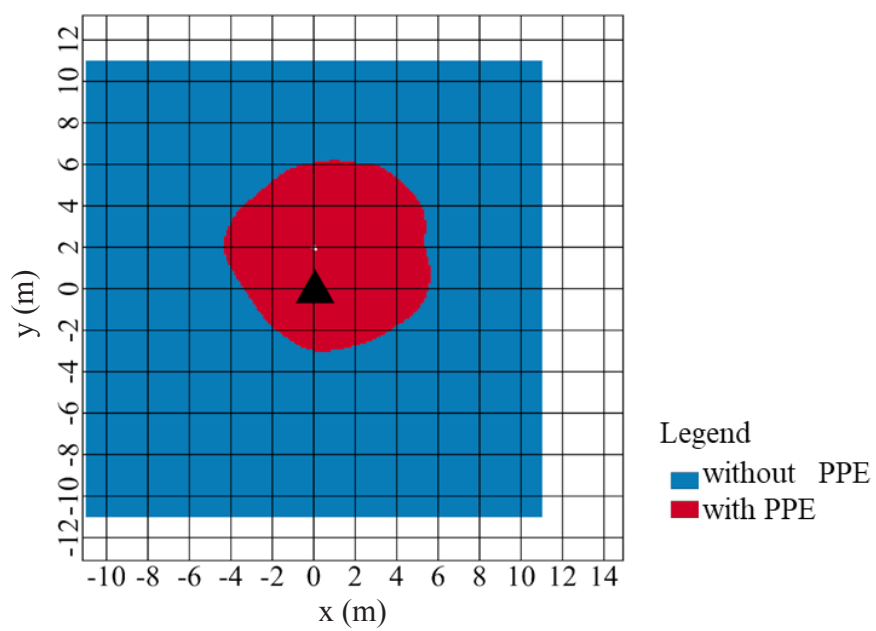

Figure 3. Map of unhealthy zones for operators involved in operations with the power tiller 


\section{Conclusions}

1. It was possible to characterize the spatial structure of the noise emitted by a power tiller and to evaluate its variability through the wave semivariogram fitting model with the WLS method. It was possible to define the unhealthy zones.

2. Under the conditions studied, both the machine operator and people around the tractor within a $6 \mathrm{~m}$ radius from the emitting source are subject to the harmful health effects caused by noise exposure, since they exceeded the values recommended by the regulatory standard.

3. The use of ear protectors is recommended for both the power tiller operators and professionals who support the machine operation.

\section{ACKNowledgements}

The authors thank the Conselho Nacional de Desenvolvimento Científico e Tecnológico (CNPq), the Fundação de Amparo à Pesquisa do Estado do Rio de Janeiro (FAPERJ), the Colégio Técnico da Universidade Federal Rural do Rio de Janeiro (CTUR), the Coordenação de Aperfeiçoamento de Pessoal de Nível Superior (CAPES) for granting scholarships and the PET/ SISU/MEC.

\section{Literature Cited}

ABNT - Associação Brasileira de Normas Técnicas. NBR 9999: Medição do nível de ruído, no posto de operação de tratores e máquinas agrícolas. Rio de Janeiro: ABNT, 1987. 12p.

Alves, A. D. da S.; Costa, F. R. L. da; Cortez, J. W.; Dantas, A. C. da S.; Nagahama, H. de J. Níveis de potência sonora emitidos por trator agrícola em condições estáticas e dinâmicas. Pesquisa Agropecuária Tropical, v.41, p.110-119, 2011. http://dx.doi. org/10.5216/pat.v41i1.9741

Baesso, M. M.; Gazzola, M.; Bernardes, S.; Brandelero, E.; Modolo, A. Avaliação do nível de ruído, itens de segurança e ergonomia em tratores agrícolas. Brazilian Journal of Biosystems Engineering, v.9, p.368-380, 2015. http://dx.doi.org/10.18011/ bioeng2015v9n4p368-380

Brisolin, D.; Bidel, R. M. R.; Severo, C. D. M.; Zago, V. L. P.; Paini, J. F. P. Ruído: Conhecimento dos trabalhadores e seus efeitos no organismo. Revista de Enfermagem, v.8, p.42-54, 2012.

Cressie, N.; Hawkins, D. M. Robust estimation of the variogram. Mathematical Geology, v.12, p.115-125, 1980. https://doi. org/10.1007/BF01035243

Fernandes, M.; Morata, T. C. Estudo dos efeitos auditivos e extraauditivos da exposição ocupacional a ruído e vibração. Brazilian Journal of Otorhinolaryngology, v.68, p.705-713, 2002. https:// doi.org/10.1590/S0034-72992002000500017

Ferraz, G. A. e S.; Silva, F. C. da; Nunes, R. A.; Ponciano, P. F. Variabilidade espacial do ruído gerado por uma derriçadora portátil em lavoura cafeeira. Coffee Science, v.8, p.276-283, 2013. http://dx.doi.org/10.25186/cs.v8i3.431

Ferraz, G. A. e S.; Silva, F. M. da; Carvalho, L. C. C.; Alves, M. de C.; Franco, B. C. Variabilidade espacial e temporal do fósforo, potássio e da produtividade de uma lavoura cafeeira. Engenharia Agrícola, v.32, p.140-150, 2012. https://doi.org/10.1590/s010069162012000100015
Ferreira, I. O.; Santos, G. R. dos; Rodrigues, D. D. Estudo sobre a utilização adequada da krigagem na representação computacional de superfícies batimétricas. Revista Brasileira de Cartografia, v.5, p.831-842, 2013.

Gonçalves, C. G. de O.; Couto, C. M. do; Carraro, J. M.; Leonelli, B. S. Avaliação da colocação de protetores auriculares em grupos com e sem treinamento. Revista CEFAC, v.11, p.345-352, 2009. https://doi.org/10.1590/S1516-18462009000200021

Gonçalves, S. S.; Cortez, J. W.; Arcoverde, S. N. S.; Machado, N. S.; Nagahama, H. de J. Ensaio de opacidade e nível de ruído de um trator agrícola. Revista Engenharia na Agricultura, v.21, p.244252, 2013. https://doi.org/10.13083/reveng.v21i3.394

Guida, H. L.; Taxini, C. L.; Gonçalves, C. G. de O.; Valenti, V. E. Evaluation of hearing protection used by police officers in the shooting range. Brazilian Journal of Otorhinolaryngology, v.80, p.515-521, 2014. https://doi.org/10.1016/j.bjorl.2014.08.003

Isaaks, E. H.; Srivastava, R. M. An introduction to applied geostatistics. New York: Oxford University, 1989. 561p.

Leão, R. N.; Dias, F. A. M. Perfil audiométrico de indivíduos expostos ao ruído atendidos no núcleo de saúde ocupacional de um hospital do município de Montes Claros, Minas Gerais. Revista CEFAC, v.12, p.242-249, 2010. https://doi.org/10.1590/S151618462010000200010

Magalhães, A. T.; Cortez, J. W.; Nagahama, H. de J. Nível de ruído de um trator agrícola em função da rotação, da distância, da velocidade e da condição do solo obtido por meio de decibelímetro com e sem proteção de vento. Energia na Agricultura, v.27, p.27-44, 2012.

Missio, C.; Cortez, J. W.; Motomiya, A. V. de A.; Quequeto, W. D. Variabilidade espacial do nível de ruído externo em rotações de trabalho. Energia na Agricultura, v.30, p.104-108, 2015. http:// dx.doi.org/10.17224/EnergAgric.2015v30n2p104-108

MTE - Ministério do Trabalho e do Emprego. Atividades e operações insalubres: NR-15. Available on: <http://trabalho.gov.br/index. php/seguranca-e-saude-no-trabalho/normatizacao/normasregulamentadoras $>$ Access on: Set. 2017.

Mueller, T. G.; Pusuluri, N. B.; Mathias, K. K.; Cornelius, P. L.; Barnhisel, R. I.; Shearer, S. A. Map quality for ordinary kriging and inverse distance weighted interpolation. Soil Science Society of America Journal, v.68, p.2042-2047, 2004. http://dx.doi. org/10.2136/sssaj2004.2042

Nascimento, E. M. S.; Viliotti, C. A.; Mion, R. L.; Albiero, D.; Monteiro, L. D. A. Assessment of noise level emitted by micro tractor in static and dynamic conditions. Semina: Ciências Agrárias, v.34, p.11211128, 2013. https://doi.org/10.5433/1679-0359.2013v34n3p1121

Pimenta Junior, C. G.; Delmond, J. G.; Cunha, J. P. B.; Couto, R. F.; Leonídio, D. M.; Reis, E. F. dos. Análise espacial do nível de ruído emitido por trator agrícola. Revista Brasileira de Ciências Agrárias, v.7, p.515-520, 2012. https://doi.org/10.5039/agraria. v7i3a 1228

Poje, A.; Potočnik, I.; Danilović, M.; Antonić, S. A case study of the impact of skidding distance on tractor operator exposure to noise. Baltic Forestry, v.22, p.357-364, 2016.

Pyrcz, M. J.; Deutsch, C. V. The whole story on the hole effect. Geostatistical, v.18, p.3-5, 2003.

Quantum GIS Development Team. QGIS versão 2.14.15. 2017. Available on: <https://www.qgis.org/pt_BR/site/>. Access on: Jul. 2017. 
R Development Core Team. R: A language and environment for statistical computing. 2014. Available on: <https://www.r-project.org/>. Access on: Jun. 2017.

Ribeiro Junior, P. J.; Diggle, P. J. GeoR: A package for geostatistical analysis. R-News, v.1, p.14-18, 2001.

Rinaldi, P. C. N.; Fernandes, H. C.; Silveira, J. C. M. D.; Magno Júnior, R. G.; Minetti, L. J. Características de segurança e níveis de ruído em tratores agrícolas. Engenharia na Agricultura, v.16, p.215-224, 2008.

Spadim, E. R.; Marasca, I.; Batistuzzi, M. M.; Denadai, M. S.; Guerra, S. P. S. Dependência espacial do ruído de tratores agrícolas em diferentes rotações do motor. Revista de Agricultura Neotropical, v.2, p.29-33, 2015. https://doi.org/10.32404/rean.v2i3.270
Veiga, R. K.; Merino, E. A. D.; Gontijo, L. A.; Masiero, F. C.; Merino, G. S. A. D. Estudo comparativo da usabilidade de comandos direcionais para duas concepções de máquinas agrícolas. Revista Produção Online, v.15, p.830-858, 2015. https:// doi.org/10.14488/1676-1901.v15i3.1712

Webster, R.; Oliver, M. A. Geostatistics for environmental scientists: Statistics in practice. 2.ed. London: John Wiley e Sons, 2007. 333p. https://doi.org/10.1002/9780470517277

Yanagi Junior, T.; Schiassi, L.; Rossoni, D. F.; Ponciano, P. F.; Lima, R. R. D. Spatial variability of noise level in agricultural machines. Engenharia Agrícola, v.32, p.217-225, 2012. https:// doi.org/10.1590/S0100-69162012000200002 